\title{
Kendsgerninger og normativ politisk teori $^{1}$
}

Normativ politisk teori søger at formulere og begrunde politiske principper. Principper er generelle bud på, hvilke grunde der er for at indrette samfundet på bestemte måder, eller hvilke betingelser samfundsindretningen bør leve op til, fx. for at sikre retfærdighed eller legitimitet. Spørgsmålet er, hvad forholdet er mellem sådanne normative påstande og deskriptive påstande om kendsgerninger. Dette er samtidig spørgsmålet om, hvad forholdet er mellem normativ politisk teori og empirisk statskundskab. 1) Hvordan og hvorfor involverer politisk teori generelle normative principper? 2) Hvilken grad af "realisme" kan og bør man forvente af politisk teori, og hvad vil det sige, at en politisk teori er realistisk? 3) På hvilken måde er realiserbarhed et relevant krav at stille til politiske teorier? 4) Afhænger politiske princippers begrundelse af kendsgerninger, eller forudsætter enhver inddragelse af kendsgerninger i begrundelsen for principper, at der findes nogle principper, der er uafhængige af kendsgerninger?

\section{Politisk teori og principper}

Normativ politisk teori handler om den teoretiske, dvs. systematiske, saglige og begrundede, diskussion af politiske spørgsmål om, hvordan samfundet bør indrettes, eller hvordan dets faktiske indretning bør vurderes. Teorien er i første omgang "politisk" i kraft af dens genstand, dvs. at det politiske består i, at de spørgsmål, teorien søger at bidrage til besvarelsen af, er politiske spørgsmål om samfundets indretning og udøvelse af magt. Teorien er dog også politisk $\mathrm{i}$ en anden forstand, nemlig den at den søger at give grunde for at mene noget bestemt om sådanne politiske spørgsmål. Det er dette, der karakteriserer normativ politisk teori, fx. til forskel fra politisk teori, der søger at forklare politiske fænomener. Normativ politisk teori forbliver i en vis forstand inden for det politiske. Men samtidig er der tale om et akademisk forsøg på at sige noget systematisk og sagligt om de politiske spørgsmål, hvilket adskiller politisk teori fra ideologi eller politisk retorik. Et centralt træk ved politisk teori er, at man forsøger at opstille normative principper, som kan anvendes i besvarelse af de nævnte politiske spørgsmål.

Hvorfor er principper centrale for normativ politisk teori? Teorien adskiller sig fra (dele af) almindelig politisk diskussion og retorik ved, at specifikke vurderinger eller forskrifter, fx. om en regerings demokratiske legitimitet el- 
ler hvordan skattesystemet bør reformeres for at blive mere retfærdigt, skal kunne begrundes på en saglig og rationel måde. Det vil sige, at man søger at opstille argumenter, hvor den specifikke vurdering eller forskrift optræder som konklusion, der følger eller støttes af nogle præmisser. Da konklusionen er normativ (indeholder en værditilskrivelse eller et handlingsanvisende "bør"), må mindst én af præmisserne også være normativ. Dette er en banal logisk pointe: Argumenter giver grunde til at acceptere konklusioner ved at vise, at man bør acceptere konklusionen, givet at man accepterer præmisserne. I den stærkeste form for argumenter, logisk gyldige deduktive argumenter, skyldes dette, at man ikke kan forkaste konklusionen og samtidig acceptere præmisserne uden derved at modsige sig selv, fordi det, konklusionen hævder, allerede er indeholdt i præmisserne. Dette betyder i forbindelse med normative argumenter, at det normative element i konklusionen allerede må ligge i præmisserne. Som påpeget af David Hume (2007, bog 3, del 1, sektion 1, \$27) betyder dette mere generelt, at man ikke kan slutte fra "er" til "bør". Lige gyldigt hvor stor en ulighed et skattesystem fx. tillader, følger der intet heraf om, hvorvidt systemet er retfærdigt eller ej; ulighed er deskriptiv, hvorimod (u)retfærdighed er normativ. Derfor er der behov for normative præmisser, hvis man vil opstille lødige argumenter for normative konklusioner.

Men hvorfor skal normative præmisser have form af principper, dvs. generelle påstande, om $\mathrm{fx}$. retfærdighed eller legitimitet $\mathrm{i}$ almindelighed? Dette skyldes, at man ønsker at kunne begrunde svar på politiske spørgsmål med gode grunde, dvs. at de normative konklusioner altså faktisk skal støttes af præmisserne. Dette er relevant i forhold til nogle former for såkaldt "kontekstualistisk" politisk teori, der forkaster "teoretiske" tilgang til politik (Owen og Tully, 2007). Påstanden er nogle gange, at det er helt forfejlet at foreskrive teoretiske svar på politiske spørgsmål uafhængigt af demokratiske processer. Dette er dog en simpel misforståelse, da politisk teori ikke er et alternativ til demokratisk beslutningstagning, men et systematisk bud på, hvad demokratiske beslutningstagere har grunde til at stemme for (Swift og White, 2008: 55). Kontekstualisters mere interessante påstand er, at man bør se på de konkrete forhold ved forskellige politiske sager i deres konkrete kontekst (deraf navnet), og at vi uddrager vores normative vurderinger direkte heraf uden inddragelse af generelle politiske teorier (Modood, 2009: 75).

Problemet med megen kontekstualisme er, at forkastelsen af generelle normative teorier efterlader det som et åbent spørgsmål, hvorfor man skulle acceptere de normative konklusioner om bestemte særtilfælde, hvis man ikke i forvejen deler vurderingen heraf. Tag fx. Tariq Modoods synspunkt at et retfærdigt forhold mellem statsmagt og religiøse trossamfund ikke kræver fuld adskillelse 
af stat og kirke eller nogen anden form for mere formel ligestilling af trossamfund, men blot at majoritetskirkens privilegier på passende vis udstrækkes til også at gælde religiøse minoritetsgrupper (Modood, 2007). Hvis begrundelsen for dette synspunkt ikke appellerer til mere generelle principper for retfærdighed, legitimitet i almindelighed eller religionens betydning i særdeleshed, har man så herved givet radikale sekularister og nationalkonservative tilhængere af privilegerede nationalkirker gode grunde til at fravige deres synspunkter? Problemet er dels, at et rent kontekstualistisk argument i virkeligheden strander som en enkeltsagsvurdering, som man så bare kan være enig eller uenig i, dels at argumentet ikke giver yderligere muligheder for at bedømme, hvilke politiske handlingsanvisninger, der følger, fx. hvad en "passende" ustrækning af privilegier til minoritetsreligioner i praksis er (Lægaard, 2008).

I modsætning til rene former for kontekstualisme (hvis sådanne overhovedet findes) søger politisk teori at formulere principper, der kan fungere som præmisser for konklusioner. Dette har den fordel, at diskussionen ikke strander som en evaluativ uenighed om enkeltsager, men tillader en dialektisk dynamik. Hvis argumentet for en bestemt normativ konklusion $\mathrm{fx}$. appellerer til en bestemt opfattelse af statslig legitimitet, så vil uenighed om den normative konklusion kunne føres tilbage til den normative præmis, således at en opponent, der forkaster konklusionen, enten må forkaste præmissen eller vise, at argumentet er ugyldigt. Hvis argumentet er gyldigt, viser det så enten, hvori den evaluative uenighed mere grundlæggende består, fx. i synet på legitimitet, eller at opponenten er inkonsistent, hvis vedkommende accepterer præmissen men nægter at acceptere dens implikation i det konkrete tilfælde.

Spørgsmålet er nu, hvordan man kan begrunde principper, og nærmere bestemt på hvilken måde deskriptive påstande om faktuelle kendsgerninger kan eller ikke kan indgå i denne slags begrundelser? Dette spørgsmål er af interesse i forbindelse med en afklaring af forholdet mellem politisk teori og deskriptive tilgange til politik og samfundsforhold. Men der er desuden grund til at diskutere dette spørgsmål nærmere, da der inden for politisk teori er en række forskellige synspunkter på forholdet mellem kendsgerninger og principper, som de sidste år er blevet mere udtalte end tidligere. Denne artikels emne er altså både interessant i forhold til afklaring af forholdet mellem forskellige discipliner og i forhold til interne metodologiske uenigheder inden for politisk teori.

I det følgende vil jeg derfor se på tre aktuelle diskussioner omkring forholdet mellem kendsgerninger og principper, nemlig spørgsmålene 1) om politisk teori skal være "realistisk", og hvad der overhovedet kan forstås ved et sådant krav; 2) om politisk teori skal være realiserbar og i hvilken forstand; og 3) om fundamentale principper mere generelt må være uafhængige af kendsgernin- 
ger, som hæudet af G.A. Cohen? Diskussionen starter i den mere praktiske og politiske ende og bevæger sig mod de mere teoretiske og filosofiske spørgsmål.

\section{Rawlsiansk politisk metodologi}

Inden for politisk teori har der bredt sig en utilfredshed med den dominerende opfattelse af disciplinens formål og metode. Den dominerende opfattelse kan karakteriseres som rawlsiansk, idet John Rawls med sin epokegørende $A$ Theory of Justice fra 1971 af mange ikke alene betragtes som den vigtigste bidragsyder til, at politisk teori igen fik mod på at tage normative (frem for rent begrebslige eller historiske) problemstillinger op på en systematisk måde, men også formulerede den metode, som mange (hvad enten de i øvrigt er enige eller uenige med Rawls) betragter som definerende for politisk teori.

Rawls præsenterede sine retfærdighedsprincipper som begrundede i kraft af, at de ville blive valgt af personer i en ideal hypotetisk kontraktsituation, "den oprindelige position". Men han begrundede i bredere forstand sin teori ud fra det, han kaldte "bred reflekteret ligevægt" (1999a: 18-19, 42-45). Ifølge Rawls er politiske principper begrundede, hvis deres implikationer stemmer godt overens med (er i "ligevægt" med) vores "velovervejede intuitioner" samt vores baggrundsteorier og generelle faktuelle viden. Så retfærdighedsprincipperne er ikke bare begrundede, fordi de ville blive valgt i den oprindelige position, men fordi den oprindelige position angiveligt er indrettet således, at de principper, der ville blive valgt her, indfanger en række centrale intuitioner om betydningen af lighed, upartiskhed, respekt for personer osv. Dette kan dels fortolkes som en kohærensteori om begrundelse, da begrundelsen består i sammenhængen mellem principper og intuitioner. Dels er det en relativt ufilosofisk og pragmatisk ide, idet begrundelse handler om at overbevise andre om at acceptere konklusioner, fordi de følger af præmisser, man er enige om (Norman, 1998: 280-282).

Synet på begrundelse kobles endvidere med en decideret metode for politisk teori. Rawls foreslår nemlig, at politisk teori bedrives analogt med den hypotetisk-deduktive metode: Man foreslår et bestemt princip (fx. utilitarisme) og udleder derpå implikationer af dette princip for konkrete enkeltsager (fx. fordelingsspørgsmål), som man så "tester" i forhold til ens intuitioner, der altså fungerer ligesom de empiriske videnskabers observationsdata. Hvis der er uoverensstemmelse, må man enten forkaste eller justere princippet eller ens intuitioner. Således bør politisk teori ifølge Rawls søge at nærme sig den bedst mulige ligevægt mellem principper og intuitioner. Dette er givetvis ikke en præcis beskrivelse af en systematisk metode i streng forstand som politisk teori 
faktisk følger, men nærmere en heuristik for politisk argumentation, der inkorporerer en række common sense ideer (Norman, 1998).

\section{Hvis realisme er svaret, hvad var så spørgsmålet?}

Rawls er altså eksponent for en opfattelse af politisk teori som normativ, systematisk og metodisk. Imod denne opfattelse rejser en række kritikere, man kan kalde "realister", en række kritikpunkter: Rawlsiansk politisk teori kritiseres for at være grundlæggende upolitisk, idet den ikke tager højde for, hvad politik er i praksis, nemlig et spørgsmål om udøvelse af magt i situationer, hvor uenigheder er uundgåelige (Williams, 2005). Politisk teori anklages desuden for at antage, at man kan "løse" politiske problemstillinger ved rationel argumentation, hvorigennem magtudøvelse kan gøres uproblematisk, fordi de grundlæggende uenigheder kan opløses til fordel for en normativ konsensus om principper. Politisk teori er således i virkeligheden en tilsidesattelse af politik (Honig, 1993; Newey, 2003) til fordel for en idealiserende form for moralisme, der ikke kan realiseres eller gøre en forskel i politisk praksis (Leiter, 2001).

Ifølge sådanne kritikere bør politisk teori i stedet være realistisk. "Realisme" svarer her ikke nødvendigvis til politisk realisme som forstået i international politik, dvs. deskriptive synspunkter om, at international politik er et anarkistisk magtspil drevet af staters egeninteresse, hvor moralske motiver enten ikke kan eller ikke bør spille nogen rolle (sidste tilføjelse åbner mulighed for, at politisk realisme også kan være et (paradoksalt) normativt synspunkt). Realisme i denne artikels sammenhæng betegner i stedet et synspunkt om politisk teori, dvs. et anden ordens synspunkt om mulighederne for eller kravene til formulering og begrundelse af normative politiske teorier. Det er dog ikke helt klart, præcist hvad det vil sige, at en politisk teori er realistisk. Og det er endnu mindre klart, om realisternes kritikpunkter mod Rawlsiansk politisk teori rammer plet, og om man bør acceptere de alternativer, realisterne (noget uklart) forestiller sig.

Der er forskellige forståelser af "realisme" blandt kritikerne. Ifølge én karakteristik er en teori urealistisk, hvis den udelader betydelige aspekter ved eller kendsgerninger om politik. Realisme betegner derimod overensstemmelse mellem teorien og faktisk politik, hvilket dels er et gradsspørgsmål, dels tillader, at den samme teori kan have forskellige grader af realisme i forskellige henseender (Emmerich, 2009: 196). Denne definition viser, at realismediskussionen handler om forholdet mellem principper og kendsgerninger. Definitionen giver desuden god mening til kritikken af rawlsiansk politisk teori for at være urealistisk - det er jo centralt hos Rawls, at en række forhold, der normalt er centrale i politik, fx. interessekonflikter, magtforhold og aktørers tendens 
til at pleje deres egeninteresse, simpelthen udelades; retfærdighedsprincipperne udledes af den oprindelige position, hvor denne slags forhold ikke tillades at have nogen effekt på valget af principper for at sikre disses upartiskhed. Men selv former for politisk teori, der ikke benytter den rawlsianske kontrakt som argumentationsredskab, fokuserer på argumenter og grunde og kan altså (med rette) anklages for at være rationalistiske og i den forstand urealistiske; lødige argumenter, logisk konsistens og systematisk begrundelse spiller sjældent nogen særlig fremtrædende rolle i faktisk politik.

Men den skitserede forståelse af realisme efterlader det som et åbent spørgsmål, i hvilken udstrækning det overhovedet er ønskværdigt, at politisk teori er realistisk. Hvis man ønsker systematisk at kunne begrunde normativ stillingtagen til politiske forhold, så er overensstemmelse med faktisk politik ikke nødvendigvis et kriterium for en teoris kvalitet. Det ville jo betyde, at den bedste teori var den, der foreskrev, at tingene skulle være lige præcis som de er, dvs. en teori som hæver status quo op som ideal og dermed forfægter, at vi lever i den bedste af alle mulige politiske verdener. At gøre realisme i denne forstand til en målestok for teoriers kvalitet ville være at sætte lighedstegn mellem magt og ret - en form for teoretisk konservatisme eller defaitisme.

Dette urimelige resultat kan undgås på forskellige måder. På den ene side kan realisters kritik ses som udtryk for, at de i virkeligheden sætter spørgsmålstegn ved ambitionen om at bedrive normativ politisk teori. Hvis man ønsker at indtage et normativt (handlingsvejledende og/eller vurderende) perspektiv på politik, må det være fordi, man tager for givet, at tingene ikke nødvendigvis er, som de bør være, fx. at magt ikke nødvendigvis er ret. Normativ teori forudsætter således et skel mellem det normative og det deskriptive - ikke nødvendigvis i enkeltsager, men rent principielt - hvor man ikke kan slutte fra sidstnævnte til førstnævnte. Derfor er normativ teori nødvendigvis urealistisk i den nævnte forstand (Estlund, 2008: 263). Når realister kritiserer politisk teori for at være urealistisk, kan dette derfor simpelthen skyldes, at de er uenige i ambitionen om at bedrive normativ politisk teori.

Nogle realister er forholdsvis eksplicitte på dette punkt. Raymond Geuss skriver således, at politisk teori bør være realistisk, dvs. ikke spørge, hvordan folk burde handle, men hvordan politiske institutioner faktisk fungerer i bestemte samfund, og hvad der virkelig motiverer folk til at handle (2008: 9). Han mener, at man slet ikke bør skelne mellem deskriptiv og normativ politisk teori (2008: 16-17). Glen Newey skriver tilsvarende, at problemet med politisk teori er, at den ofte er uegnet til at forklare politiske fænomener og ikke giver nogen forståelse af faktisk politiske fænomener, hvilket skyldes bevægelsen fra deskriptiv til normativ teori (2003: 2-4). Sådanne kritikker er simpelthen 
udtryk for uenighed med hensyn til målsætningen for megen nyere politisk teori, der jo netop ikke prøver at beskrive eller forklare faktisk politik, men at formulere og begrunde principper til vurdering af politikken (Leiter, 2001). Realisme mht. politisk teori minder her om retsrealisme, der i stedet for at spørge normativt, hvilken dom der er den rigtige, spørger deskriptivt, hvilken dom der kan forudses. Da det urealistiske ved politisk teori skyldes, at formålet er at være normativ, er der ikke noget at sige til, at man finder det urealistiske problematisk, hvis man er uenig i dette formål. Det er klart, at realisme er et krav til teorier, der vil beskrive, forklare og forudsige faktisk politik. Men da normativ politisk teori ikke deler dette formål, er realisme altså her et svar på et helt andet spørgsmål. Så hvis den realistiske kritik udelukkende skyldes denne uenighed om mål, er kritikken simpelthen en fejltagelse.

Der kunne dog også være grunde til at være realist, selv hvis man deler ambitionen om at være normativ. En af realister ofte fremført grund er, at svar på normative spørgsmål skal henvise til forhold, der i sig selv er politiske, fx. fordi den normative teori ellers forfalder til en irrelevant form for moralisme. Bernard Williams forfægtede et sådan synspunkt. Han forstod realisme som det at bedrive politisk teori uafhængigt af moralfilosofi (2005: 3). Williams var enig i, at politisk teori skal være normativ, idet den grundlæggende behandler spørgsmål om legitimering af magt. Ifølge Williams er kravet om legitimering iboende i det politiske og ikke et udefrakommende krav til politik. Politik handler om, hvordan staten med magt sikrer orden, sikkerhed og muliggør samarbejde, når menneskelig sameksistens nødvendigvis er konfliktuel. Politik involverer således nødvendigvis uenighed og magt (jf. Newey, 2003: 7-8).

Dette er deskriptive påstande. Men politik har altså også ifølge Williams en iboende normativ dimension, nemlig at ikke alle måder at løse konflikter ved magt på er legitime; politik skal forestille at være svaret på problemet omkring uenighed og konflikt, hvilket i sig selv medfører, at ikke en hvilken som helst udøvelse af magt kan være legitim - ellers bliver det angivelige svar på problemet til en del af problemet. Så hvis politik i sig selv implicerer et skel mellem legitim og illegitim magtudøvelse, er det normative spørgsmål om legitimitet en del af det, vi må forstå for at forstå politik. Problemet opstår nu ifølge Williams, når politisk teori prøver at besvare spørgsmålet om legitimeringen af magt ud fra værdier og principper importeret fra moralfilosofi, fx. idealer om frihed, lighed, autonomi, rettigheder, solidaritet osv. At besvare det politiske spørgsmål ud fra moralske idealer er så en form for moralisme, der misforstår spørgsmålet, da politik jo netop handler om situationer, hvor man ikke kan tage enighed om den slags idealer for givet. Så selv om politisk teori er nor- 
mativ, skal den altså ifølge Williams være realistisk i den forstand, at den skal undgå moralisme.

Nu kan man på den ene side diskutere, om politisk teori faktisk misforstår politik på den måde, som Williams (samt Geuss, Newey m.fl.) hævder. På den anden side kan man overveje, om man virkelig kan og bør undgå moralisme i politisk teori. Det er lidt mærkværdigt, at Williams klandrer rawlsiansk politisk teori for at ignorere, at politik essentielt involverer magt, og at uenighed er uundgåelig. Det er jo netop det, Rawls tager udgangspunkt i, når han formulerer spørgsmålet, som retfærdighedsteorien skal svare på. Ifølge Rawls bliver retfærdighed først et spørgsmål, når det, han med Hume kalder "retfærdighedens omstændigheder", er opfyldt, dvs. at der er moderat mangel på ressourcer, og folk hverken er renlivede egoister eller altruister (1999a: 109-112). Hvis der er radikal mangel på ressourcer, eller folk er radikale egoister, er retfærdighed håbløs, og hvis der er overflod af ressourcer, eller alle er altruister, er retfærdighed overflødig. Retfærdighed bliver kun et relevant spørgsmål, når der er noget at fordele, men folk er uenige om, hvordan det bør fordeles. Når Rawls skal begrunde retfærdighedsprincipperne, har han endvidere i sin senere politiske liberalisme eksplicit blik for, at uenighed om værdispørgsmål er et uundgåeligt vilkår i moderne liberale samfund (1996: xviii, xxvi, 36). Endelig påpeger han, at den retfærdige indretning af samfundet skal kunne legitimeres på en måde, der tager højde for denne uundgåelige uenighed, da den jo er et spørgsmål om, hvordan staten skal udøve magt over borgerne (1996: xlvi, 136-137, 216-217). Så Rawls definerer den politiske teoris spørgsmål på samme måde som Williams. Hans svar på spørgsmålet er desuden øjensynligt i overensstemmelse med Williams krav om at undgå moralisme, da den sene Rawls ønsker at kunne udlede retfærdighedsprincipperne af ideer i den offentlige politiske kultur i moderne liberale demokratier, der ikke forudsætter bestemte moralske begrundelser (1996: 8, 13-14).

Spørgsmålet er, om Rawls politiske liberalisme er politisk på den rigtige (her, realistiske) måde. Det er også et åbent spørgsmål, om Rawls' politiske omfortolkning af sin teori, herunder den fritstående begrundelse af retfærdighedsprincipperne som rent politiske, faktisk fungerer. Min pointe er blot, at Rawls definition af emnet for og formålet med politisk teori slet ikke er så forskellig fra Williams, uagtet om man accepterer hans svar på spørgsmålet eller ej.

Det bredere spørgsmål er, om man overhovedet kan undgå moralisme i normativ politisk teori, og om man bør, hvis man kan? Man kan overveje, hvad der egentlig kan fungere som et svar på Williams spørgsmål. Ifølge Williams afhænger det af den historiske kontekst, hvad der giver mening som legitimering af magt. I vestlige demokratier er en eller anden form for liberalisme 
(individuelle frihedsrettigheder, demokrati etc.) nødvendig for at legitimere statsmagten. Men en sådan historisk relativering af legitimitet risikerer at underminere den fundamentale forskel på magt og ret, som Williams selv gør sig til fortaler for. Hvis magt er legitim, blot der kan fortælles en historie om den, som "giver mening" for folk, så kan al magtudøvelse i princippet legitimeres. Williams forsøger selv at undgå sådanne relativistiske implikationer ved at læse et kritisk princip ud af sin definition af det politiske, nemlig at accept af magt ikke tæller som legitimering, hvis accepten selv er et produkt af magten (2005: 6). Men at magt ikke er ret, og at accept af magt ikke i sig selv sikrer legitimitet, er begge negative teser, der begrænser svar på spørgsmålet, men ikke leverer nogen positive grunde for bestemte svar. For at begrunde svar, må man nødvendigvis importere yderligere normative forestillinger som målestok for magtens legitimitet. Målestokken kan ikke udledes af selve det politiske, der jo er et normativt spørgsmål, ikke en normativ præmis der kan begrunde et svar. Så hvis moralisme betegner det, at man henter normative standarder uden for det politiske, er spørgsmålet ikke, om man bør undgå moralisme i politisk teori, men om politisk teori kan undgå at være moralistisk?

\section{Realisme som realiserbarhed}

Det er langt mere rimeligt at forstå politisk realisme, ikke som modstand mod moral og påkaldelsen af moralske principper i politisk teori som sådan, men som modstand mod moralisme i en snavrere forstand som overdreven, upassende eller fordrejet påkaldelse af moral i politik (Coady, 2008: 14). Anken angår ikke, at man appellerer til moralske principper som standarder for legitimitet eller retfærdighed, hvilket er uundgåeligt, men at man udstrækker moralske principper til at gælde for spørgsmål, der ikke er moralske, eller giver overdreven vægt til bestemte moralske hensyn. Moralisme kan også tage form af en for høj grad af abstraktion, eller at moralske hensyn gøres absolutte. En særlig interessant form for moralisme, der ofte er genstand for realisters kritik, er, at det er umuligt at leve op til de påberåbte moralske standarder, eller at vurderinger baseres på idealer, der ikke er realiserbare. Moralisme i denne forstand gør politisk teori urealistisk i den tidligere introducerede forstand og er dermed et spørgsmål om forholdet mellem normative principper og empiriske kendsgerninger.

Et umiddelbart svar på denne anklage er at acceptere, at "bør" implicerer "kan", og at urealiserbarhed derfor altid bør undgås i handlingsvejledende udsagn (Cohen, 2008: 250, 253; Estlund, 2008: 265; Freeman, 2009: 47). Hvis noget er umuligt, kan det ikke være en pligt at gøre det. De fleste politiske teoretikere accepterer dette generelle princip, der lader kendsgerninger om 
det mulige sætte grænser for handlingsvejledninger. Der er ikke desto mindre uenigheder om, hvad der faktisk er muligt. Her er forskellen mellem realister og ikke-realister ofte nærmere, at realister tager mange flere begrænsninger for givet end ikke-realister. Problemet er dog, at det er et ret åbent spørgsmål, hvad der er muligt og kan realiseres (Rawls, 1999b: 12; Miller, 2008: 42). Der er selvfølgelig visse ting, der er decideret (logisk eller fysisk) umulige, fx. at være to steder på samme tid eller at bringe de døde tilbage til live, men de fleste politiske idealer er ikke logisk eller fysisk urealiserbare.

Urealiserbarhed er altid relativ, fx. til folks kapaciteter eller bestemte omstændigheder (Coady, 2008: 55-56). Urealiserbarhedsanklagen kan derfor ofte mødes med et modspørgsmål om, hvorvidt det er rimeligt at tage disse kapaciteter eller omstændigheder for givet (Lægaard, 2006). Hvis det politiske spørgsmål er, hvordan man kan legitimere magt, og bestemte legitimitetskrav afvises som baserede på urealiserbare idealer, er det ofte et lige så relevant spørgsmål, hvorfor disse idealer er urealiserbare. Hvis dette skyldes omstændigheder, der i sig selv er magtforhold, er produkter af magt eller kunne ændres politisk, så er omstændighedernes legitimitet et politisk spørgsmål på linje med det oprindelige spørgsmål, som i lige så høj grad kan gøres til genstand for diskussion.

Realister udbreder ofte urealiserbarhedsanklagen til forhold, der ikke er strengt taget umulige at realisere. Fx. mener realister ofte, at politisk teori ikke i tilstrækkelig grad indretter sig efter kendsgerninger om aktørers faktiske motivation. Stater hævdes at være motiverede udelukkende af egeninteresse, skatteborgere hævdes ikke at ville være villige til at bidrage til omfordeling til grupper, der ikke ligner dem selv, og arbejdere hævdes ikke at ville gøre en indsats i fravær af økonomiske incitamenter. Sådanne angivelige kendsgerninger påberåbes som grunde til at forkaste henholdsvis idealisme i international politik, indvandreres adgang til velfærdsydelser, og omfordeling med henblik på sikring af økonomisk lighed. Påstanden er her ikke, at teorier, der medfører denne slags krav, er urealiserbare i streng forstand. Påstanden er i stedet, at vi bør tage de forhold, der gør kravene urealiserbare, for givet. Bemærk at der nu er tale om en normativ indvending om, at teorier forbryder sig mod andre vigtige hensyn, frem for en deskriptiv påstand om, at de kræver det umulige (Miller, 2008: 42-43). Idealisme i international politik kan fx. hævdes at underminere staters evne til at varetage andre værdifulde funktioner. Williams' kritik af Rawls kan forstås i dette lys; hvor Rawls hævder, at retfærdighed er den primære målestok for vurdering af institutioner, går institutioners evne til at løse det politiske spørgsmål om etablering af orden ifølge Williams forud (Galston, 2009: 113-14). Men dette er en normativ frem for en empirisk indvending - altså et internt problem i politisk teori om afvejning af forskellige 
politiske værdier, idealer eller hensyn, frem for et eksternt spørgsmål mellem politisk teori og empirisk samfundsvidenskab om forholdet mellem principper og kendsgerninger.

Dette antyder, at realisme ofte bare er en særlig pessimistisk form for normativ politisk teori, der fokuserer på potentielle problemer med at implementere politiske idealer og derfor anbefaler, at politik skal holde sig til det grundlæggende, nemlig opretholdelse af orden (Galston, 2009: 120; Sangiovanni, 2009: 228-232). Men igen: Dette er en normativ indvending mod overambitiøs eller naiv idealisme og moralisme; det er normative værdier, der begrunder afvisningen af moralisme, ikke empiriske kendsgerninger. Som sådan minder realisme meget om konservatisme, der også er en slags "negativ utilitarisme" domineret af pessimisme på fornuftens vegne og frygt for de utilsigtede følger af politisk reformisme. Om man skal være pessimistisk eller ej er et normativt spørgsmål, der selvfølgelig blandt andet handler om, hvad konsekvenserne af forskellige handlinger vil være. Men det er normative idealer, der gør disse konsekvenser relevante, og i den forstand er denne slags diskussioner interne i forhold til politisk teori.

At politisk teori ikke kan undgå appel til moralske værdier eller præmisser, og at realisters anker ofte selv (måske ubevidst) hviler på normative vurderinger, betyder ikke, at der ikke kan være gode grunde til at bedrive realistisk politisk teori. Det kommer helt an på, hvad formålet er, og hvilken funktion teorien skal have. Der kan være grund til at tage kendsgerninger for givet, også selv om de ikke er nødvendige i streng forstand. Hvis man fx. ønsker at levere handlingsanvisninger om bestemte afgrænsede politiske spørgsmål, fx. legalisering af stoffer, eller skattesystemets fordelingsprofil, under faktiske omstændigheder, fx. dagens Danmark, så bedriver man anvendt politisk teori, der selvfølgelig tager en lang række kendsgerninger for givet. Men anvendte argumenter er stadig afhængige af normative præmisser, der overskrider de givne omstændigheder. Og omstændighederne kunne vise sig problematiske, hvis de blev gjort til genstand for vurdering. Der er så tale om det, Rawls kalder non-ideal politisk teori (1999b: 7-8, 215-216, 308-309). Dette er en vigtig og relevant form for politisk teori, der desuden er afgørende ifølge rawlsiansk metodologi, da de fundamentale principper til dels er begrundede i kraft af at kunne fungere som præmisser for anvendte argumenter, hvis konklusioner forekommer rimelige. Anvendt politisk teori er altså ikke sekundær eller mindre grundlæggende end abstrakte principper; ifølge reflekteret ligevægtsmetoden er de lige vigtige. 


\section{Er principper afhængige af kendsgerninger?}

De ovenfor diskuterede spørgsmål om realiserbarhed angår handlingsvejledninger, der skal være realiserbare, da "bør" implicerer "kan". Kendsgerninger om det mulige sætter grænser for praktiske forskrifter. Handlingsvejledninger er desuden afhængige af kendsgerninger, fordi sådanne forskrifter er konklusioner på anvendte normative argumenter, der ud over principper har empiriske beskrivelser af sagens omstændigheder som præmisser. Ud over de nævnte uenigheder om, hvad der er realiserbart i praksis, er der dog også et mere generelt spørgsmål angående de principper, der fungerer som præmisser i argumenter for handlingsvejledninger. G.A. Cohen (2008) har rejst spørgsmålet, om disse principper afhænger af empiriske kendsgerninger. Cohen accepterer, at kendsgerninger er relevante i forhold til, hvordan vi bør handle politisk, men benægter, at vores fundamentale normative grunde for at handle politisk er "faktaafhængige".

Denne diskussion kan ikke uden videre afgøres med henvisning til, at "bør" implicerer "kan". Dette krav kan ikke nødvendigvis overføres fra handlingsvejledninger til de principper, der begrunder handlingsvejledninger. De har for det første ikke nødvendigvis selv form af handlingsvejledninger. Principper kunne fx. være værdier, der fortæller, hvilke tilstande der (alt andet lige) er efterstræbelsesværdige, uden at præcisere, i hvilken grad værdien bør realiseres. Selv hvis principper har form af idealer, der er urealiserbare, kan de endvidere godt fungere som præmisser for handlingsvejledninger. Man kan ofte tilnerme sig idealer, der ikke kan realiseres fuldt ud. Så er der tale om såkaldt regulative idealer. Dette kan endvidere ændre, hvad der er realiserbart på længere sigt (Coady, 2008: 57-62, 74). Den slags politiske teori, der opstiller og forsvarer sådanne principper, er det, David Estlund kalder "aspirationel teori" (2008: 171, 259). Principper kan fungere som præmisser i argumenter for handlingsvejledninger, fordi de angiver kriterier for, hvornår en værdi eller et hensyn er opfyldt, fx. rigtigheds- eller legitimitetskriterier. Kriterier er ikke nødvendigvis noget, der i sig selv skal eller kan føres ud i livet. Men de er vigtige i argumenter for, hvad der skal føres ud i livet, fordi de giver den endelige forklaring på, hvorfor vi bør gøre et frem for noget andet (Freeman, 2009: 44-45).

Cohen benægter den udbredte opfattelse, at normative principper er baserede på eller afhængige af kendsgerninger om mennesket, samfundet og politisk magt. Cohens påstand er, at fundamentale principper er faktauafhængige i den forstand, at kendsgerninger ikke er blandt grundene til at acceptere principperne (2008: 231). Fx. kan princippet, at vi skal holde vores løfter, være baseret på den kendsgerning, at kun hvis folk holder deres løfter til hinanden, kan de forfølge deres livsprojekter på en succesfuld måde (Cohen, 2008: 234). 
Men denne relation mellem kendsgerning og princip skal forklares; hvorfor er kendsgerningen en grund til at acceptere princippet? Ifølge Cohen må dette skyldes et højere ordens princip, der i eksemplet fx. kunne være, at man skal hjælpe folk med at forfølge deres livsprojekter. Kendsgerningen er en grund til at acceptere princippet givet dette højere ordens princip, for princippet følger deduktivt fra det højere ordens princip og kendsgerningen - at vi skal holde vores løfter er en konklusion på et gyldigt deduktivt argument ud fra præmissen, at vi skal hjælpe folk med at forfølge deres livsprojekter, og kendsgerningen, at folk kun kan forfølge deres livsprojekter, hvis vi holder vores løfter.

I Cohens eksempler har forklaringerne på, hvorfor kendsgerninger er grunde til at acceptere principper, form som klassiske nomotetiske forklaringer. Forklaringen består i at vise, at det, der skal forklares (her, accepten af princippet), følger deduktivt af nogle initialbetingelser (kendsgerningen) og et generelt forhold (her et højere ordens princip, der ikke er afhængigt af den nævnte kendsgerning). Hvis forklaringen skal være deduktiv, må der være et højere ordens princip, som er faktauafhængigt, hvis vi ikke skal ende i en uendelig regres.

Dette betyder ikke, at alle principper må være faktauafhængige. Cohen skelner mellem fundamentale principper og afledte regulativer (rules of regulation) (2008: 253, 259-262, 265-267). Sidstnævnte er praktiske redskaber, som vi accepterer under bestemte omstændigheder, fordi konsekvensen af at handle i overensstemmelse med regulativer vil være, at vi handler rigtigt under disse omstændigheder. Som sådan svarer regulativer til det, utilitarister kalder "beslutningsprocedurer". Regulativer er altid faktaafhængige, da grunden til at acceptere dem henviser til konsekvenserne under bestemte omstændigheder. Men regulativer er samtidig afledte af mere fundamentale principper, der ligger til grund for vurderingen af konsekvenserne. De mere fundamentale principper er altså ikke afhængige af de kendsgerninger, som regulativerne afhænger af, og fungerer i stedet som det, utilitarister kalder "rigtighedskriterier". Cohens påstand er altså, at regulativer kun kan være faktaafhængige i kraft af, at der findes mere fundamentale principper, der er faktauafhængige. Der kan være flere niveauer af principper, der hver afhænger af forskellige kendsgerninger. Men ifølge Cohen må niveauerne udgøre et hierarki, hvor det mest fundamentale princip nødvendigvis er helt uafhængigt af fakta.

Cohens tese er først og fremmest en filosofisk tese, og argumentet for den har med filosofiske krav til, hvad begrundelse er, at gøre. Som sådan forekommer den ikke direkte politisk interessant. Men for så vidt at politisk teori skal leve op til krav om at være systematisk og argumenteret på en måde, der går ud over almindelig politisk retorik, er sådanne filosofiske krav alligevel relevante. Tesen kræver klarhed omkring argumentation, og som sådan kan den 
medvirke til at identificere, hvad de fundamentale principper i en given diskussion er, og dermed afklare forvirringer grundet på sammenblanding af fundamentale principper og afledte regulativer. Tesen medfører desuden, at bestemte politiske teorier og måder at bedrive politisk teori på enten er uacceptable eller ufuldstændige. Dette gælder især Rawlsianske begrundelser for retfærdighedsprincipper, der både i deres kontraktteoretiske form og i den bredere reflekteret ligevægtsmetodologi involverer omfattende påkaldelse af faktuelle forhold.

\section{Indvendinger mod Cohens tese}

Der er forskellige typer indvendinger mod Cohens tese. En relativ intern kritik, der accepterer store dele af Cohens argumentation, består i at benægte, at deduktiv følge er den eneste mulige måde at forklare, hvordan principper kan baseres på kendsgerninger (Miller, 2008: 34). En påstand kan være baseret på en anden påstand, uden at relationen mellem de to er deduktiv. Relationen kunne være evidentiel uden at være deduktiv. Fx. er påstanden, at der er en sort fugl med orange næb i min have, en grund til at acceptere påstanden, at der en solsort i min have, selv om sidstnævnte ikke følger deduktivt af førstnævnte. En påstand kan alternativt være en nødvendig forudsætning for en anden påstands sandhed. Påstanden "Abelone er dansk statsborger" er en grund til at acceptere påstanden "Abelone har stemmeret til folketingsvalget", fordi statsborgerskab er en nødvendig forudsætning for stemmeret, uden at sidstnævnte påstand følger deduktivt af den førstnævnte.

Ifølge David Miller kan sådanne ikke-deduktive relationer mellem påstande fungere som forklaringer på, hvorfor kendsgerninger er grund til at acceptere principper. Værdien af individuel valgfrihed kan fx. afhænge af den kendsgerning, at mennesker har selvbevidsthed og er i stand til at træffe valg om, hvordan vi ønsker at leve vores liv. Var dette ikke tilfældet, ville det være uforståeligt, hvorfor individuel valgfrihed skulle være værdifuld. Så kendsgerningen om menneskers selvbevidsthed og evne til at træffe valg kan være en nødvendig forudsætning for princippets sandhed (2008: 35-36). Cohen kunne selvfølgelig svare, at dette skyldes et højere ordens princip om, at hvis et væsen har selvbevidsthed og er i stand til at træffe valg, så har individuel valgfrihed værdi. Men Miller påpeger, at dette højere ordens princip bare omformulerer spørgsmålet som en betinget påstand; det, der skulle forklares, var netop, hvorfor individuel valgfrihed er værdifuld, og hvis man undrer sig over dette, vil man givetvis undre sig lige så meget over det betingede højere ordens princip (2008: 35).

Dette er en rent filosofisk kritik af Cohens argument, der udelukkende sætter spørgsmålstegn ved antagelsen om, at forklaringer på, hvorfor kendsgerninger er grund til at acceptere principper, må have deduktiv form. Hvis forkla- 
ringer ikke behøver at have denne form, er det ikke nødvendigt at forudsætte højere ordens faktauafhængige principper. Så har Cohen ikke vist, at politisk teori ikke kan være faktaafhængig på det fundamentale plan. Men der er også andre, mere eksterne kritikker af Cohens tese. De angår det mere overordnede formål med at bedrive politisk teori.

Politisk teori er ifølge Miller normativ i forstanden handlingsvejledende. Så spørgsmålet er, hvem principperne skal vejlede og hvordan? Miller accepterer her en rawlsiansk opfattelse, ifølge hvilken politisk teori skal kunne vejlede borgere i et demokratisk samfund; ikke sådan forstået at borgere faktisk skal kunne gennemføre eller individuelt handle ud fra den politiske teori, men på den måde at den politiske teori skal kunne give et billede af, hvordan samfundet kunne være, der kan fungere som regulativt ideal og give mening til, hvad vi politisk kan gøre nu (Rawls, 1999b: 128; Miller, 2008: 44). Rawlsianeren Samuel Freeman giver en mere udførlig karakteristik af denne opfattelse: Politisk teori skal kunne udfylde en social rolle som falles grundlag for begrundelse af politik i samfund som vores, hvor folk er uenige om etiske værdier og opfattelser af det gode. Derfor må en politisk teori være forenelig med almindelige borgeres moralske og psykologiske kapaciteter og må ikke frustrere deres grundlæggende mulighed for at forfølge det gode liv (2009: 46-55). Hvis politisk teori skal spille denne rolle, må selv de fundamentale principper være gennemskuelige og forståelige, hvilket Cohens komplicerede hierarki af principper ikke er. Selv om Rawls' retfærdighedsprincipper afhænger af kendsgerninger, så er de desuden fundamentale i den forstand, at de udgør den ultimative standard for, hvad der er rigtigt og forkert politisk set. Fx. stopper begrundelsen for, hvorfor en given fordeling er uretfærdig, ved Rawls' differensprincip, selv om grunden til at acceptere dette princip i sig selv appellerer til andre værdier, metodologiske principper og kendsgerninger. Men disse grunde til at acceptere differensprincippet er ikke i sig selv grunde til at anse en bestemt fordeling for retfærdig eller uretfærdig (Freeman, 2009: 44-45).

Cohen er simpelthen uenig i denne opfattelse af den politiske teoris rolle. Selv om principper er handlingsvejledende, afhænger deres sandhed eller autoritet ikke af deres evne til at vejlede handling. Politisk teori handler ikke (kun) om, hvad vi skal gøre, men om, hvad vi skal mene (2008: 267-68). De filosofiske krav til argumentativ klarhed går altså ifølge Cohen forud for den politiske teoris sociale rolle; politisk teori er først og fremmest filosofi, der blot tilfældigvis handler om politiske spørgsmål. Cohens synspunkt er således det diametralt modsatte af den politiske realisme, der netop hævdede, at politik går forud for filosofi. Rawls og Miller placerer sig imellem disse to ekstremer; på den ene side er politisk teori grundlæggende politisk, i den forstand at teorien har en poli- 
tisk funktion og ikke kun skal leve op til filosofiske krav til argumentation. På den anden side er den politiske funktion ikke dikteret af, hvad der er politisk realistisk i den banale forstand, at faktiske politikere kan eller vil gennemføre det her og nu. Det politiske er heller ikke en eller anden ikke-moralsk størrelse, der udelukker appeller til moralske hensyn, som hos Williams. Rawls' karakteristik af politiske teorier som forsøg på at formulere "realistiske utopier", dvs. mulige forbedringer af det faktiske, skal forstås i dette lys (1999b: 6-7, 11-12). Så en mulig diagnose af uenighederne mellem Cohen og Rawls, lige som mellem realister og Rawls, er, at de simpelthen søger svar på forskellige spørgsmål eller forstår spørgsmålet forskelligt.

\section{Afslutning: Tilbage til reflekteret ligevægt}

Afslutningsvis vil jeg overveje et tredje svar på Cohens kritik: Måske er reflekteret ligevægtsmetodologi ikke så faktaafhængig, som både Cohen og de kritiserede rawlsianere lader til at mene. Ifølge reflekteret ligevægtsmetodologi er principper begrundede i den udstrækning, deres implikationer i konkrete tilfælde stemmer overens med de af vores intuitioner, vi efter nærmere overvejelse fastholder. Kendsgerninger spiller flere roller i denne metode: Dels er den umiddelbare genstand for vurdering princippernes implikationer for konkrete tilfælde. Man anvender principperne på konkrete tilfælde, hvilket kræver, at principperne suppleres med deskriptive præmisser om de faktiske omstændigheder i de konkrete tilfælde. Dels er målet bred reflekteret ligevægt, dvs. at man ikke kun søger ligevægt mellem principper og normative intuitioner, men også mellem principper og bredere baggrundsteorier og viden om samfundsmæssige forhold.

Men er principper ifølge denne politiske metodologi afhængige af kendsgerninger på den måde, som Cohen hævder og kritiserer? Der er to forskellige måder at forstå reflekteret ligevægtsmetoden på. I et tredjepersons perspektiv søger den politiske teoretiker at finde principper, som bedst muligt indfanger og forklarer folks moralske intuitioner. Man tager politiske ideer fra den offentlige politiske kultur som faktuelle kendsgerninger, der skal forklares. Samtidig fungerer disse kendsgerninger som evidens for principperne, hvis principperne stemmer overens med kendsgerningerne (Miller, 2008: 41). I så fald er kendsgerninger altså blandt grundene til at acceptere principperne. Men bemærk at øvelsen så er rent deskriptiv og eksplanatorisk: Både de politiske principper og de normative intuitioner er faktuelle størrelser, der skal forklares og fungerer som forklaring. Konklusionen på en sådan øvelse har form af en god forklaring, ikke af et sæt normative principper, der fremsættes som faktisk bindende for vores handlinger. 
Hvis man derimod forstår reflekteret ligevægt i forste person, er ens intuitioner ikke faktuelle kendsgerninger, der skal forklares, men normative vurderinger, der skal begrundes. Principper er i sig selv begrundede, hvis de leverer den bedste begrundelse for vores velovervejede intuitioner - dette er det kohærentistiske element i Rawls' metode, der blandt andet involverer den slags ikkededuktive relationer mellem påstande, som Miller fremhæver. I den forstand er intuitionerne blandt grundene til at acceptere principperne. Men så er der ikke længere tale om et forhold mellem kendsgerninger og principper, men mellem forskellige normative påstande af varierende generalitet. Så det er ikke åbenlyst, at reflekteret ligevægt i første persons perspektiv gør accepten af principper afhængig af kendsgerninger. Det er selvfølgelig rigtigt, at reflekteret ligevægtsmetoden involverer overvejelser om konkrete tilfælde og almene samfundsforhold. Men dette er ikke ensbetydende med, at det er kendsgerningerne, der begrunder principperne. Dette ville også være mærkværdigt, eftersom man jo så ville have sluttet fra "er" til "bør". Der er nærmere tale om, at kendsgerningerne er en del af det, man artikulerer sine normative intuitioner i forhold til, og i forhold til hvilket man overvejer, om man vil holde fast i eller revidere sine intuitioner. Men det er overensstemmelsen med intuitionerne, der udgør begrundelsen for principperne, ikke kendsgerningerne som sådan.

\section{Note}

1. Tak for kommentarer til Rasmus Sommer Hansen, Nils Holtug, Kasper LippertRasmussen, Søren Flinch Midtgaard, Per Mouritsen, Tore Vincents Olsen og en reviewer.

\section{Litteratur}

Coady, C.A.J. (2008). Messy Morality: The Challenge of Politics, Oxford: Clarendon Press.

Cohen, Gerald Allan (2008). Rescuing Justice and Equality, Harvard: Harvard University Press.

Emmerich, Ze'ev (2009). "Political Theory and the Realistic Spirit", pp. 195-218 i Duncan Bell (red.), Political Thought and International Relations: Variations on a Realist Theme, Oxford: Oxford University Press.

Estlund, David (2008). Democratic Authority: A Philosophical Framework, Princeton: Princeton University Press. 
Freeman, Samuel (2009). "Constructivism, Facts, and Moral Justification”, pp. 41-60 i Thomas Christiano og John Christman (red.), Contemporary Debates in Political Philosophy, Chichester: Wiley-Blackwell.

Galston, William (2009). "Realism and Moralism in Political Theory: The Legacies of John Rawls", pp. 111-129 i Shaun Young (red.), Reflections on Rawls: An Assessment of his Legacy, Farnham: Ashgate.

Geuss, Raymod (2008). Philosophy and Real Politics, Princeton: Princeton University Press.

Honig, Bonnie (1993). Political Theory and the Displacement of Politics, Ithaca: Cornell University Press.

Hume, David (2007). A Treatise of Human Nature: A Critical Edition, David Fate Norton og Mary J. Norton (red.), Oxford: Clarendon Press.

Leiter, Brian (2001). "Classical Realism", pp. 244-267 i Ernest Sosa og Enrique Villanueva (red.), Social, Political, and Legal Philosophy: Philosophical Issues, Volume 11, John Wiley \& Sons.

Lægaard, Sune (2006). "Feasibility and Stability in Normative Political Philosophy: The Case of Liberal Nationalism", Ethical Theory and Moral Practice, 9. årg., nr. 4, pp. 399-416.

Lægaard, Sune (2008). "Moderate Secularism and Multicultural Equality", Politics, 28. årg., nr. 3, pp. 160-168.

Miller, David (2008). "Political Philosophy for Earthlings", pp. 29-48 i David Leopold og Marc Stears (red.), Political Theory: Methods and Approaches, Oxford: Oxford University Press.

Modood, Tariq (2007). Multiculturalism: A Civic Idea, Cambridge: Polity.

Modood, Tariq (2009). "Moderate Secularism and Multiculturalism", Politics, 29. årg., nr. 1, pp. 71-76.

Newey, Glen (2003). After Politics: The Rejection of Politics in Contemporary Liberal Philosophy, Basingstoke: Palgrave.

Norman, Wayne (1998). '”Inevitable and Unacceptable?' Methodological Rawlsianism in Anglo-American Political Philosophy", Political Studies, 46. årg., nr. 2, pp. 276-294.

Owen, David og James Tully (2007). "Redistribution and Recognition: Two Approaches", pp. 265-291 i Anthony Simon Laden og David Owen (red.), Multiculturalism and Political Theory, NewYork: Cambridge University Press.

Rawls, John (1996). Political Liberalism, paperback ed., New York: Columbia University Press.

Rawls, John (1999a). A Theory of Justice, rev. ed., Cambridge, MA: Harvard University Press. 
Rawls, John (1999b). The Law of Peoples; with "The Idea of Public Reason Revisited", Cambridge, MA: Harvard University Press.

Sangiovanni, Andrea (2009). "Normative Political Theory: A Flight from Reality?" pp. 219-239 i Duncan Bell (red.), Political Thought and International Relations: Variations on a Realist Theme, Oxford: Oxford University Press.

Swift, Adam og Stuart White (2008). "Political Theory, Social Science, and Real Politics", pp. 49-69 i David Leopold og Marc Stears (red.), Political Theory: Methods and Approaches, Oxford: Oxford University Press.

Williams, Bernard (2005). In the Beginning Was the Deed, red. Geoffrey Hawthorn, Princeton: Princeton University Press. 